\title{
The Predictive Value of the Systemic Immune-inflammation Index as a New Prognostic Marker for Disability in Patients with Multiple Sclerosis
}

\author{
MS Hastalarında Engellilik İçin Yeni Bir Prognostik Belirteç Olarak Sistemik \\ İmmün-enflamasyon İndeksinin Prediktif Değeri
}

\author{
(1) Hikmet Saçmacı, (®) Tülin Aktürk, () Nermin Tanık \\ Yozgat Bozok University Faculty of Medicine, Department of Neurology, Yozgat, Turkey
}

\begin{abstract}
Objective: Multiple sclerosis (MS) is a condition involving central nervous system invasion by immune-inflammatory cells. In this study, we investigated whether the systemic immune-inflammation index (SII) could predict disability cross-sectionally as a novel and useful tool in patients with MS.

Materials and Methods: We retrospectively reviewed the medical records of 148 patients with MS and 84 healthy controls and gathered the relevant clinicallaboratory data. SII in the remission period was calculated using the equation (SII: Platelet count $\mathrm{x}$ neutrophil count/lymphocyte count). The odds ratio of each immune formulation index was calculated by logistic regression analysis. In addition, the cut-off value, sensitivity and specificity of SII were calculated using receiver operating characteristics curve analysis.

Results: Age and sex characteristics were similar in the groups ( $>>0.05)$. All values obtained through complete blood counts were significantly lower in the patient group $(\mathrm{p}<0.05)$. It was seen that the Expanded Disability Status scale (EDSS) was particularly correlated with the neutrophil-lymphocyte ratio and SII ( $\mathrm{p}=0.013,0.037$ rho: $0.225,0.192$, respectively). In addition, we found that SII [ExpB: 0.015, 95\% confidence interval: $(0.999-1.003) ; \mathrm{p}<0.001]$ was associated with disease disability in the MS groups formed according to EDSS. Furthermore, the cut-off value for SII was 254.51 x $10^{3} / \mathrm{ul}$ with $37 \%$ specificity and $95.5 \%$ sensitivity.
\end{abstract}

Conclusion: A high SII may be a promising prognostic marker that is an easily available, inexpensive, and effective tool for predicting the disease disability in MS. Future studies with a larger number of patients may confirm our results.

Keywords: Complete blood count, systemic immune-inflammation index, multiple sclerosis, disability, platelet, neutrophil

$\ddot{O} \mathbf{z}$

Amaç: Multipl skleroz (MS) hastalı̆̆ı doğuştan gelen ve kazanılmış immün sistem disfonksiyonunun özürlülük artışına yol açtı̆̆ santral sinir sistemi istilası durumudur. Biz bu çalışmada, MS hastalarında yeni ve kullanışlı bir araç olarak sistemik immün-enflamasyon indeksinin (SII) kesitsel olarak disabiliteyi tahmin edip edemeyeceğini araştırdık.

Gereç ve Yöntem: Yüz kırk sekiz MS hastasının tıbbi kayıtlarını retrospektif olarak inceledik ve klinik-laboratuvar verilerini elde ettik. Atak dışı dönemdeki SII, (SII: Trombosit sayısı x nötrofil sayısı/lenfosit sayısı) denklemi ile hesaplandı. Elde edilen hemogram parametreleri sağlıklı kontrol grubu ile karşılaştırıldı. Expanded Disability Status scale (EDSS) $>3$ ve EDSS $<3$ olarak oluşturan gruplarda lojistik regresyon analizi ile immün parametrelerin olasılık oranları hesapland 1 . Ayrıca SII'nın eşik değeri, duyarlılık ve özgüllükleri alıcı işletim karakteristiğ i analizi ile elde edildi.

Bulgular: Hastaların ortanca yaşı 39, kontrol grubunun 36 olup kadın erkek oranı gruplar arasında benzerdi (p>0,05). Hasta grubunda trombosit, nötrofil ve monositin lenfosite oranlanması ile edilen tüm değerler anlamlı düşüktü $(\mathrm{p}<0,05)$. EDSS’nin özellikle nötrofil-lenfosit oranı ve SII ile korele olduğu görüldü ( $\mathrm{p}=0,013,0,037$ rho: 0,225, 0,192). Ayrıca EDSS'ye göre oluşturulan MS gruplarında SII'nin ( $\mathrm{p}=0,000$ ExpB: 0,015, güven aralığ 1 \%95 0,999-1,003) hastalık disabilitesi ile ilişkili olduğunu saptadık. Ayrıca SII için cut-off değeri $\% 37$ spesifite ve $\% 95,5$ sensitiflik oranı ile 254,51 x $10^{3} / \mathrm{ul} \mathrm{olarak} \mathrm{bulundu.}$

Sonuç: Yüksek bir SII, MS'de hastalık disabilitesi göstergesi olarak umut vadeden elde edilmesi kolay, ucuz ve etkili prognostik bir belirteç olabilir. Daha uzun takipli büyük ölçekli çalışmalara ihtiyaç vardır.

Anahtar Kelimeler: Tam kan sayımı, sistemik immün-enflamasyon indeksi, multipl skleroz, sakatlık, trombosit, nötrofil

Address for Correspondence/Yazışma Adresi: Hikmet Saçmacı MD, Yozgat Bozok University Faculty of Medicine, Department of Neurology, Yozgat, Turkey Phone: +90 5052621012 E-mail: hsacmaci@ hotmail.com ORCID: orcid.org/0000-0003-1480-0562

Received/Geliş Tarihi: 03.07.2020 Accepted/Kabul Tarihi: 07.01.2021

${ }^{\circ}$ Copyright 2021 by Turkish Neurological Society

Turkish Journal of Neurology published by Galenos Publishing House. 


\section{Introduction}

Multiple sclerosis (MS) causes disability due to axonal loss as a result of the autoreactive T-lymphocyte attack in the central nervous system (CNS) (1). Although the initial and definitive etiology of MS is unknown, there are multifactorial interactions in MS pathogenesis, one of these, myelin specific T-cells, can trigger and modulate the passage of inflammatory leukocytes into the CNS. Increasing evidence suggests that B-cells also play a major role in the pathogenesis and development of axonal damage (2). However, it is controversial whether inflammation induces neurodegeneration or neurodegeneration occurs independently of inflammation (3).

In addition to monocytes, neutrophils have been reported to play a role in the increase of inflammatory response in the pathophysiology MS (4). In many areas of medicine and various neurologic diseases, the neutrophil-lymphocyte ratio (NLR) and monocyte-lymphocyte ratio (MLR), inexpensive and easily available components of the standard complete blood count (CBC), have been increasingly used as clinical biomarkers of pathologic inflammation (5). In addition, platelet activation, degranulation, and platelet-leukocyte interactions can affect the pathophysiology of all neurodegenerative diseases including MS (6). In physiologic conditions, CNS has an extremely low level of immune cells, such as neutrophils and lymphocytes. Platelets can induce inflammation by increasing the adhesion of leukocytes to the endothelium. Furthermore, Langer et al. (7) proved that platelets were trapped in chronic active demyelinating MS lesions.

Currently, the systemic immune-inflammation index (SII), as a new inflammatory marker, has been emphasized as an index calculated from systemic immune cells from platelet, neutrophil, and lymphocyte counts (8). SII, which exhibits a positive correlation with neutrophil and platelet counts and an inverse correlation with lymphocyte count, was first described by Hu et al. (9). In numerous studies, the successful predictive value of SII has been shown in evaluating survival, especially in malignant diseases $(10,11,12,13,14)$. Also, in a recent study, Kim et al. (15) found that SII was associated with poor prognosis in anti-neutrophil cytoplasmic antibodies (ANCA)-related vasculitis.

The Expanded Disability Status scale (EDSS) is used most frequently to show disease disability in MS, a neurodegenerative disease, and it is a very effective method to evaluate morbidity $(16,17)$. Unsurprisingly, increased neurologic disability has a significant impact on the lives of a relatively young patient population affected by MS (18). Therefore the main goal of the MS treatment protocol should include preventing or reducing the progression of long-term disability (19). Hence, physicians involved in managing MS treatment require reliable, valid, and sensitive tools that measure patient disability in terms of clinical and laboratory methods (20). The aim of this study was to investigate whether SII has an effect on the outcome of the disease and whether it could be used as a simple and useful predictor in MS with comprehensive statistical methods.

\section{Materials and Methods}

This is a retrospective case-control study comparing patients with MS and healthy controls. We reviewed consecutive patients with MS who were admitted, treated, and followed up between January 2017 and February 2020. The inclusion criteria were as follows: (1) age range: 18 to 65 years, and (2) diagnosis of MS according to the 2017 McDonald criteria (21). The exclusion criteria were as follows: Hematologic and autoimmune comorbidities, serious infections, severe kidney and liver dysfunction, traumatic bone fractures in the previous 6 months, cardiac diseases, cerebral vascular diseases, anti-coagulant treatment of any kind, history of infection or any inflammatory condition within the previous month, preoperative hematologic markers, patients who had received steroid therapy within the last month, exacerbation of MS, and pregnant women.

\section{Clinical Data}

Among a total sample of 148 patients with MS, 120 were enrolled in the study. Demographic, clinical, laboratory data were analyzed such as age, sex, the presence of additional diseases, current treatment received and the duration of final treatment, and disease duration. The duration of the treatment and drug compliance information was confirmed from the patients' records. Eighteen patients were excluded from the study because reliable clinical data were not available. In addition, three patients with concurrent chronic infections and two with additional vasculitic disease were excluded from the study.

The neurologic disability of the patients was estimated using the EDSS at the time of blood sampling (22). Accordingly, the patients were categorized into two groups and analyzed; those with mild disability (EDSS $<3.0$ ), and those with moderate/high disability (EDSS $\geq 3.0$ ) (23). In addition, data were analyzed by forming a control group from 84 healthy individuals with age and sex compatibility.

\section{Complete Blood Counts}

Venous blood samples of the patients and age-controlled healthy controls were taken from the antecubital vein into vacuum tubes after 12 hours of fasting. Blood sampling was collected into ethylenediamine tetraacetic acid tubes for a CBC. The CBC and biochemical parameters were examined, and the lesions on magnetic resonance imaging of the brain and spinal cord and attack status were evaluated. Attack (relapse) was defined as the onset of acute neurologic symptoms lasting 24 hours or more, and the attack status was recorded. Neutrophil (reference range: 2-6.9 $\times 10^{3} / \mathrm{ul}$ ), lymphocyte (reference range: 0.6-3.4x103/ul), platelet (reference range: 142-424x103/ul), monocyte (reference range: $0-0.9 \times 10^{3} / \mathrm{ul}$ ) hemoglobin (reference range: $12-18.1 \mathrm{~g} / \mathrm{dl}$ ) measurements were gathered at the specified reference intervals. The results of the automatic $\mathrm{CBC}$ with differential were obtained through electronic queries of the hospital records.

Evaluations of SII, Neutrophil-platelet-monocyte/ Lymphocyte Ratio

SII is based on peripheral lymphocyte, neutrophil and platelet counts and was calculated using the formula SII: $(\mathrm{PxN}) / \mathrm{L}$, where $\mathrm{P}, \mathrm{N}$ and $\mathrm{L}$ express preoperative peripheral platelet, neutrophil and lymphocyte counts, respectively (9). We calculated the NLR, MLR and platelet to lymphocyte ratio (PLR) as follows: NLR: Neutrophil count/lymphocyte count, PLR: platelet count/ lymphocyte count and MLR: Monocyte/lymphocyte count.

\section{Ethical Standards}

The study protocol was approved by the Yozgat Bozok University Faculty of Medicine Ethics Committee (decision no: 
2017-KAEK-189_2020.02.26_12, date: 26.02.2020). This study was conducted in accordance with the ethical principles and national regulations of the Helsinki Declaration.

\section{Statistical Analysis}

Statistical analysis of all patients and controls was reported according to frequencies for categorical variables (\%), mean \pm standard deviation for parameters with normal distribution, and median $\left(25^{\text {th }}-75^{\text {th }}\right.$ percentile) for abnormal distributions. Normality assumption was evaluated using both visual methods (Q-Q plot) and the Kolmogorov-Smirnov normality test. The relationships between qualitative variables were analyzed using Pearson's chisquare tests, and the relationship between quantitative variables using Pearson's and Spearman's correlation tests. Differences between groups were evaluated using a continuous Student's t-test or the Mann-Whitney $U$ test for continuous data. The cut-off value, sensitivity and specificity of the hematologic data that could affect EDSS were calculated using receiver operator characteristic (ROC) curve analysis and quantile regression of the observed distributions.

In the next step, significant relationships were used to build regression models (categorical and linear models for continuous output variables) on disease disability. In terms of binary logistic regression analysis, significance levels of the models were given with Nagelkerke $\mathrm{R}^{2}$ values and the regression co-efficients with significance were presented. For regression models, $\mathrm{R}^{2}$ values adjusted to the significance of the models and standardized $\beta$ s with significance levels were given, $\mathrm{p}$ values less than 0.05 were considered statistically significant. Data were analyzed using the SPSS statistics software.

\section{Results}

\section{Demographic Characteristics and Prognosis}

A total of 120 patients with MS fulfilled the required inclusion criteria. The median age of the patients with MS was 39 (range: 31 $45)$ years, and the female:male ratio was 1.92 . The median age of the healthy controls was 36 (range: $30-42$ ) years with a female:male ratio of 2.11; and there were no sex or age differences between the groups $(\mathrm{p}>0.05)$. Blood tests showed that the lymphocyte counts were lowest in patients with MS [1.71 (1.21-2.20x103/ul) vs $\left.2.23\left(1.75-2.75 \times 10^{3} / \mathrm{ul}\right) \mathrm{p}<0.001\right]$. In the patients, the median neutrophil, monocyte, and platelet counts at diagnosis were 3.98 $\mathrm{x} 10^{3} / \mathrm{ul}, 0.56 \times 10^{3} / \mathrm{ul}$, and $249 \times 10^{3} / \mathrm{ul}$ respectively ( $\mathrm{p}>0.05$, for all). The median SII at examination was $602 \times 10^{3} / \mathrm{ul}$ and the control group's value was $472 \times 10^{3} / \mathrm{ul}(\mathrm{p}=0.013)$. The demographic and clinical characteristics of the groups and treatments of the patients are shown in Table 1.

As shown in Figure 1, the NLR, MLR, PLR and SII values of the patients are presented with a bar chart (median values for patients for NLR, MLR, and PLR were 2.56, 0.33, 147.71 vs the control group whose median values were $1.84,0.23,115.50$, respectively; $\mathrm{p}<0.05)$. In the correlation analysis between EDSS value and SII and NLR in the patient group, the findings were as follows: $\mathrm{p}=0.037$, rho: 0.192 , and $\mathrm{p}=0.013$, rho: 0.225 , respectively (Figure 2). Also, no statistical significance was found in Spearman's correlation analysis between NLR, PLR, MLR and SII values and EDSS scores according to the current treatments of patients $(\mathrm{p}>0.05)$ (Table 2$)$.
Logistic Regression Analyses and Cut-off of SII for the EDSS of Patients

We grouped patients with MS who were cross-sectionally screened according to EDSS into two groups; those with mild disability (EDSS <3.0), and those with moderate/high disability (EDSS 23.0 ), and we performed logistic regression analysis to obtain the odds ratio of each variable. In this analysis, SII was found to be significantly related to the cut-off point of EDSS [expB: $0.015,95 \%$ confidence interval (CI): (0.999-1.003); $\mathrm{p}<0.001]$. Apart from this, sex, age, NLR, MLR, and PLR values were not significantly related to EDSS (Table 3 ).

Using the area under the ROC curve (AUC/ROC) (area: 0.410, 95\% CI: 0.286-0.534), we calculated the optimal cut-off value of SII at the time of the examination to estimate cross-sectional EDSS $>3$, and the strongest value of SII was found to be $254.51 \times 10^{3 /}$ ul (sensitivity $95 \%$ and specificity $37 \%$ ). The AUC in the ROC analyses of other immune indices were calculated (Figure 3).

\section{Discussion}

Currently, extensive studies on serum biomarkers are underway investigating MS disease activity and follow-up. In this study, the hypothesis that the inflammatory index negatively affected the disability and prognosis of disease was investigated. A significant relationship was found in the correlation analysis between SII and EDSS, which was found to be high in the patient group. Furthermore, results of the regression analysis concluded that SII predicted disability for EDSS $\geq 3$ with the most significant relationship compared with other parameters. In particular, we found that the cut-off value of $254.51 \times 10^{3} / \mathrm{ul}$ was significant in the course of the disease. To the best of our knowledge, this is the first study to evaluate the relationship between EDSS and SII in patients with MS.

The pathophysiologic mechanism of MS mainly involves the damage of the blood-brain barrier $(\mathrm{BBB})$ as a result of

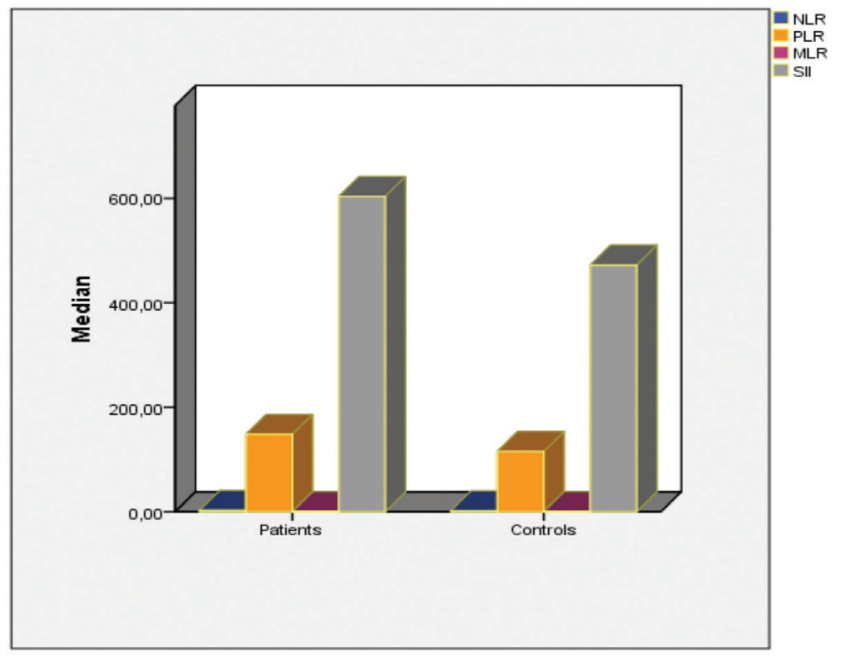

Figure 1. Comparison of NLR, PLR, MLR and SII medians between patients with multiple sclerosis and healthy controls $(\mathrm{p}<0.05$, for all).

NLR: Neutrophil-to-lymphocyte ratio, MLR: Monocyte-to-lymphocyte ratio, PLR: Platelet-to-lymphocyte ratio, SII: Systemic immuneinflammation index 
Table 1. Demographic, clinical features, treatment status and subgroup of complete blood count characteristics of study participants

\begin{tabular}{|c|c|c|c|}
\hline & Patients $(\mathrm{n}=120)$ & Controls $(n=84)$ & $\mathrm{p}$ value \\
\hline Age (years) & $39(31-45)$ & $36(30-42)$ & 0.113 \\
\hline Men, number (\%) & $41(67.9 \%)$ & $27(32.1 \%)$ & 0.763 \\
\hline Women, number (\%) & $79(65.8 \%)$ & $57(34.2 \%)$ & 0.880 \\
\hline Hemoglobin (g/L) & $13.75 \pm 1.85$ & $14.10 \pm 1.63$ & 0.159 \\
\hline Neutrophil (x109/L) & $3.98(2.88-5)$ & $4.05(3.11-5.38)$ & 0.340 \\
\hline Lymphocyte (x10\%/L) & $1.71(1.21-2.20)$ & $2.23(1.75-2.75)$ & $<0.001$ \\
\hline Monocyte (x109/L) & $0.56(0.45-0.70)$ & $0.52(0.44-0.63)$ & 0.223 \\
\hline Platelet $\left(\mathrm{x} 10^{9} / \mathrm{L}\right)$ & $249(204-302)$ & $257(223-300)$ & 0.599 \\
\hline PDW & $12(11-14)$ & $12(11-13)$ & 0.222 \\
\hline MPV, fl & $10.4(9.9-11.4)$ & $10.4(9.8-10.9)$ & 0.294 \\
\hline SII $\left(x 10^{9} / \mathrm{L}\right)$ & $602(388-1010)$ & $472(332-678)$ & 0.013 \\
\hline Disease duration (years) & $7(3-12)$ & - & - \\
\hline EDSS value & $1.5(1-2.5)$ & - & - \\
\hline Duration of final treatment (years) & $2(1-5)$ & - & - \\
\hline \multicolumn{4}{|l|}{ Treatments } \\
\hline None & $16(13 \%)$ & - & - \\
\hline Interferon & $38(31.7 \%)$ & - & - \\
\hline Glatiramer acetate & $15(12.5 \%)$ & - & - \\
\hline Dimethyl fumarate & $11(9.2 \%)$ & - & - \\
\hline Teriflunomid & $14(11.7 \%)$ & - & - \\
\hline Fingolimod & $17(14.2 \%)$ & - & - \\
\hline Ocrelizumab & $4(3.3 \%)$ & - & - \\
\hline Azathioprine & $3(2.5 \%)$ & - & - \\
\hline Natalizumab & $2(1.7 \%)$ & - & - \\
\hline
\end{tabular}

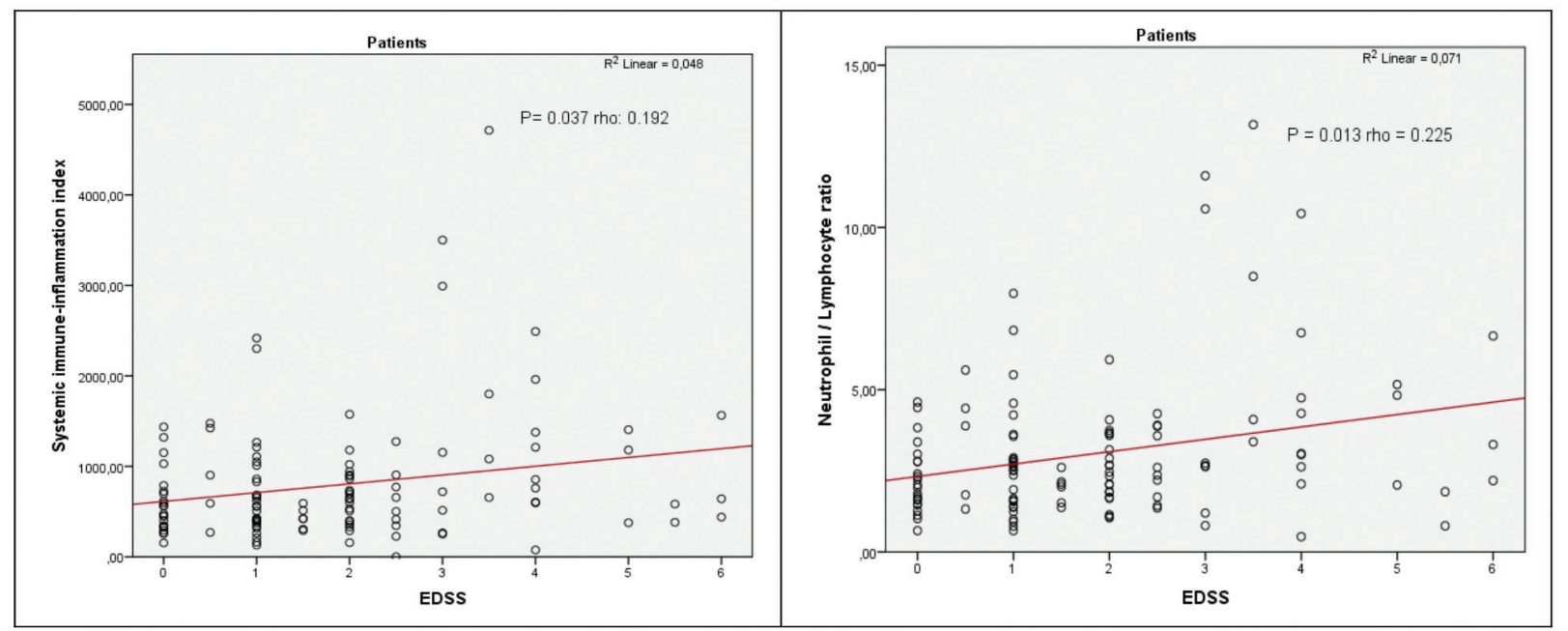

Figure 2. Correlations between Expanded Disability Status scale (EDSS) and systemic immune-inflammation index, neutrophil/lymphocyte ratio EDSS 


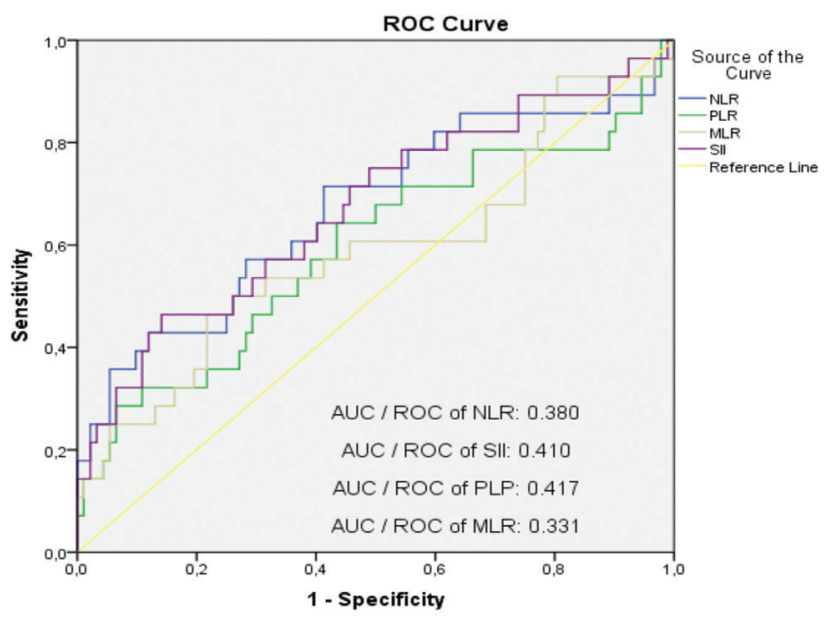

Figure 3. Receiver operating curve analysis of overall survival

ROC: Receiver operating characteristic, NLR: Neutrophil-lymphocyte ratio, PLR: Platelet-lymphocyte ratio, MLR: Monocyte-lymphocyte ratio, SII: Systemic immune-inflammation index, AUC: Area under the curve biochemical disorders and immune system changes. This barrier is responsible for supporting metabolic homeostasis and immune regulation of CNS (24). Systemic inflammation can lead to chronic neurodegeneration, and the production of pro-inflammatory cytokines causes an inflammatory response in the CNS through activation of innate or adaptive immunity (25). Platelets are also the key element responsible for physiologic changes. There is a link between platelets and MS pathophysiology, and these small cells may play a major role in neuroinflammation. Activated platelets are responsible for interacting with leukocytes and initiating increased infiltration of autoreactive T-cells, which create new neuroinflammatory lesions in the CNS $(1,2)$. In fact, SII, which has recently been the subject of research, was identified as an independent predictor of recurrence or metastasis of cancers (9). This promising marker was described as a useful and inexpensive marker that predicted clinically feasible optimal treatment options in a review investigating gastrointestinal tumors (26). There are even clinical data implying that this marker may be a more successful predictor than NLR (27). As mentioned above, this marker expressed by equation has a positive relationship with platelet and neutrophils and a negative correlation with lymphocytes. Some activation of immune-inflammatory cells

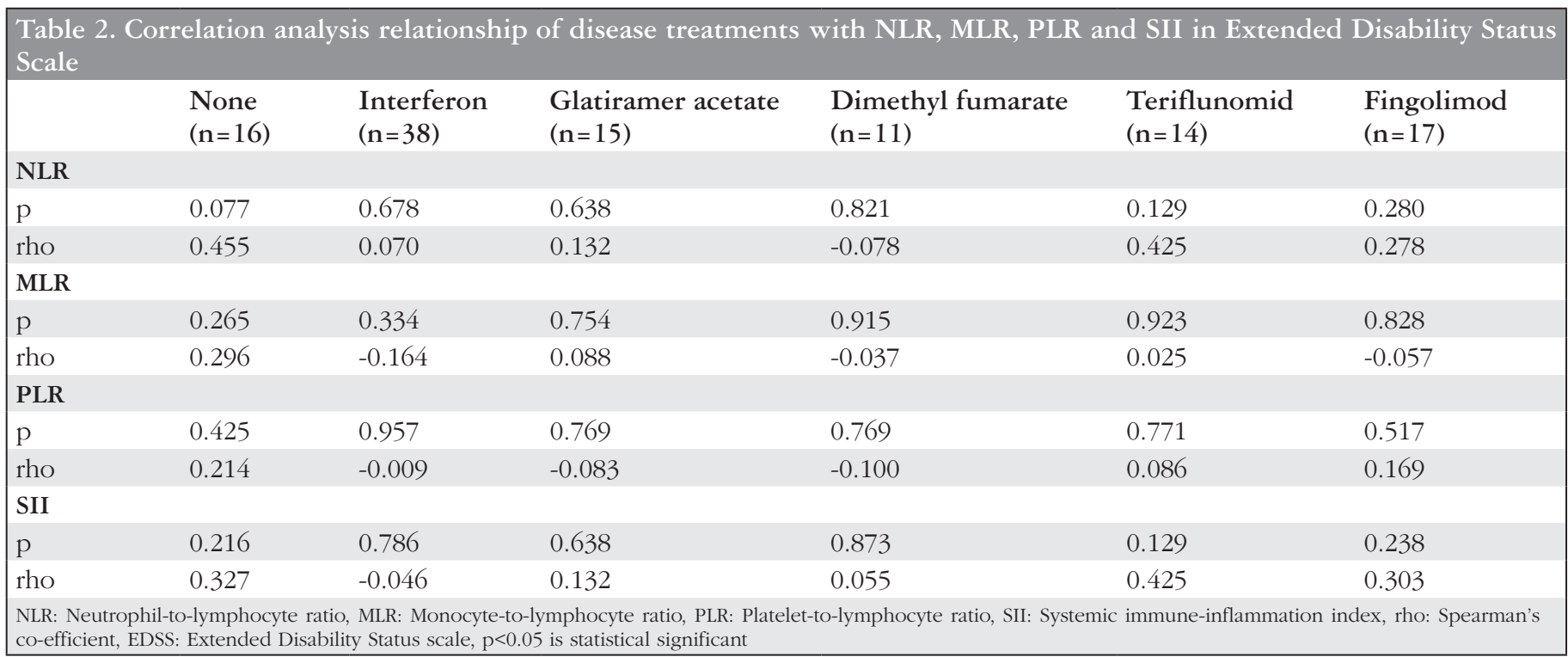

Table 3. Univariable logistic regression analyses of variables (demographic factors, complete blood count and immunological indexes) at diagnosis for the cross-sectional moderate EDSS score

\begin{tabular}{|c|c|c|c|c|c|}
\hline & Beta co-efficient & Standard error & $\begin{array}{l}\text { Confidence interval } \\
\text { lower-upper }(95 \%)\end{array}$ & $\operatorname{Exp}(B)$ & $\mathrm{p}$ value \\
\hline Constant & -1.190 & 0.216 & - & 0.304 & $<0.001$ \\
\hline Sex & 0.025 & 0.549 & $0.350-3.008$ & 1.026 & 0.963 \\
\hline Age & 0.047 & 0.024 & $0.999-1.100$ & 1.048 & 0.053 \\
\hline NLR & 0.421 & 0.311 & $0.828-2.801$ & 1.523 & 0.176 \\
\hline MLR & -1.215 & 2.066 & $0.005-17.020$ & 0.297 & 0.556 \\
\hline PLR & -0.003 & 0.004 & $0.989-1.006$ & 0.997 & 0.528 \\
\hline SII & -4.210 & 1.195 & $0.999-1.003$ & 0.015 & $<0.001$ \\
\hline
\end{tabular}


is crucial in tumorigenesis and cancer prognosis. As a result, neutrophil cells are triggered as the defense mechanism of the body in inflammation (28). Neutrophils can activate both endothelial and parenchymal cells and promote distant metastasis when making circulating tumor cell defenses (29). In addition, neutrophils suppress the activity of natural killer cells and activated T-cells, therefore neutrophils have been reported to be capable of suppressing the immune system (30). Lymphocytes are immune cells that clean tumor cells through both cellular and humoral immune mechanisms. An increase in count reflects the activation of the immune pathway (31). In addition, platelets help tumor cells escape host immunity $(26,32)$. As a result, an increase in neutrophil count and a decrease in lymphocyte count were found to predict poor prognosis (30).

The predictive value of SII, which is responsible for the poor prognosis of the disease, has also been shown in immunosuppressive drug-naive patients with ANCA-related vasculitis, an autoimmune disease (15). In a retrospectively designed study performed on 163 patients, proinflammatory cytokines and chemokines were shown to induce neutrophils and increase the functions of platelets with increased interleukin-6 (IL-6) and IL-8. However, cytokines in autoimmune diseases can also provoke lymphopenia. Thus, it was argued that the difference between the values in the formula was widened and that SII was correlated with disease prognosis (15).

Which pathways help this predictive function in MS? In studies on experimental autoimmune encephalomyelitis (EAE), an animal model of MS, it was found that neutrophil depletion prevented the pathways in the pathophysiology and contributed to EAE pathogenesis by increasing the parenchymal brain inflammation with the release of cytokines (33). Naegele et al. (34) found that neutrophils induced advanced effector mechanisms, including degranulation, oxidative burst, and the release of extracellular traps, which could result in tissue damage and demyelination, enhance T-cell activation, and disrupt the BBB. However, autoreactive T-lymphocytes contribute to the pathogenesis by facilitating inflammation and leading to more oligodendrocyte death (35). A high autophagic flux has been reported in these autoreactive T-cells in patients and the EAE mouse model (36). Proinflammatory stimulation of microglia cells causes an increase in the recruitment of inflammatory cells (lymphocytes, neutrophils, monocytes and macrophages), destroying the myelin sheath, which accelerates the formation of demyelinating lesions (6).

Contrary to expectations, activation of cytokines such as IL-6 and IL- 8 in autoimmune diseases may stimulate lymphopenia. The increase in the platelet and neutrophil counts, and the reduction in lymphocyte count, which have a triggering role in MS, would cause an increase in SII value that may be crucial for the disease and the progression of axonal damage and neurodisability cannot be prevented in line with the pathophysiologic mechanism.

In many case-control studies including relapsing-remitting MS and optic neuritis, the elevation of the NLR ratio has been demonstrated. It was also emphasized that this elevation was correlated with disability (1). In our study, we attempted to assess whether the SII equation could be a more specific marker for MS based on the literature data. According to our findings, we showed that SII could predict disability more significantly compared with all other markers with the regression analysis we performed, by setting a limit to the EDSS for the SII and an NLR value that is actually correlated with EDSS. In conclusion, with this study, we suggest that the SII might be more successful as a predictor compared with NLR.

\section{Study Limitations}

We acknowledge that there are some potential limitations in this study. The first is that it is a single-center retrospective study. Second, only patients in remission were included in the study. It would also be important to compare patients with relapsed or remission periods in different types of MS. In addition, not all laboratory values and depression anxiety levels of the patients were included in this study. Moreover, cell count and infectious markers were not evaluated in CSF. Of course, if the lesion burden distribution could be correlated with laboratory tests and CSF of the relapsing phase, we could contribute more data to the literature. In addition to the above mentioned operational limitations due to the lack of neuroimaging findings and the insufficient MSrelated data used in correlation analysis, this study should be supported by further studies. Therefore, our findings need to be confirmed by broader studies with a multicentric prospective and longitudinal design. Furthermore, differential blood count results would strongly confirm these assumptions in patients with newly diagnosed MS who have not received any prophylactic treatment. In addition, the effect of disease-modifying drugs on SII needs to be investigated to further evaluate the clinical application of this parameter.

\section{Conclusion}

This study suggests that SII, which involves assessment of neutrophils, platelets, and lymphocytes, as part of the immune response in patients with immunosuppressive drug-naive MS, may play an important role in the follow-up protocol as an inexpensive and feasible marker to assess and manage disease disability. However, in the diagnosis and follow-up of MS, if these results could be analyzed along with neurologic and imaging findings before and after treatment, it would be very useful for the literature. This study should be supported by future prospective multicenter studies with a large patient series.

\section{Ethics}

Ethics Committee Approval: The study protocol was approved by the Yozgat Bozok University Faculty of Medicine Ethics Committee (decision no: 2017-KAEK189_2020.02.26_12, date: 26.02.2020).

Informed Consent: Retrospective study.

Peer-review: Externally and internally peer-reviewed.

\section{Authorship Contributions}

Concept: H.S., Design: H.S., T.A., Data Collection or Processing: H.S., T.A., Analysis or Interpretation: H.S., N.T., Literature Search: H.S., Writing: H.S.

Conflict of Interest: No conflict of interest was declared by the authors.

Financial Disclosure: The authors declared that this study received no financial support.

\section{References}

1. D'Amico E, Zanghì A, Romano A, et al. The neutrophil-to-lymphocyte ratio is related to disease activity in relapsing remitting multiple sclerosis. Cells 2019;8:1114. 
2. D'Amico E, Zanghì A, Gastaldi M, et al. Placing CD20-targeted B cell depletion in multiple sclerosis therapeutic scenario: Present and future perspectives. Autoimmun Rev 2019;18:665-672.

3. Losy J. Is MS an inflammatory or primary degenerative disease? J Neural Transm 2013;120:1459-1462.

4. Rumble JM, Huber AK, Krishnamoorthy G, et al. Neutrophil-related factors as biomarkers in EAE and MS. J Exp Med 2015;212:23-35.

5. Hemond CC, Glanz BI, Bakshi R, Chitnis T, Healy BC. The neutrophilto-lymphocyte and monocyte-to-lymphocyte ratios are independently associated with neurological disability and brain atrophy in multiple sclerosis. BMC Neurol 2019;19:23.

6. Dziedzic A, Bijak M. Interactions between platelets and leukocytes in pathogenesis of multiple sclerosis. Adv Clin Exp Med 2019;28:277-285.

7. Langer HF, Choi EY, Zhou H, et al. Platelets contribute to the pathogenesis of experimental autoimmune encephalomyelitis. Circ Res 2012;110:12021210.

8. Hong X, Cui B, Wang M, et al. Systemic immune-inflammation index, based on platelet counts and neutrophil-lymphocyte ratio, is useful for predicting prognosis in small cell lung cancer. Tohoku J Exp Med 2015;236:297-304.

9. Hu B, Yang XR, Xu Y, et al. Systemic immune-inflammation index predicts prognosis of patients after curative resection for hepatocellular carcinoma. Clin Cancer Res 2014;20:6212-6222.

10. Zhong JH, Huang DH, Chen ZY. Prognostic role of systemic immuneinflammation index in solid tumors: a systematic review and meta-analysis. Oncotarget 2017;8:75381-75388.

11. Lu Z, Yan W, Liang J, et al. Nomogram based on systemic immuneinflammation index to predict survival of tongue cancer patients Who Underwent Cervical Dissection. Front Oncol 2020;10:341.

12. Chen L, Kong X, Wang Z, et al. Pretreatment Systemic Inflammation Response Index in Patients with Breast Cancer Treated with Neoadjuvant Chemotherapy as a Useful Prognostic Indicator. Cancer Manag Res 2020;12:1543-1567.

13. Ozbek E, Besiroglu H, Ozer K, Horsanali MO, Gorgel SN. Systemic immune inflammation index is a promising non-invasive marker for the prognosis of the patients with localized renal cell carcinoma. Int Urol Nephrol 2020;52:1455-1463.

14. Wang D, Hu X, Xiao L, et al. Prognostic Nutritional Index and Systemic Immune-Inflammation Index Predict the Prognosis of Patients with HCC. J Gastrointest Surg 2021;25:421-427.

15. Kim Y, Choi H, Jung SM, et al. Systemic immune-inflammation index could estimate the cross-sectional high activity and the poor outcomes in immunosuppressive drug-naïve patients with antineutrophil cytoplasmic antibody-associated vasculitis. Nephrology (Carlton) 2019;24:711-717.

16. Noseworthy J, Vandervoort M, Wong C, Ebers G. Interrater variability with the Expanded Disability Status Scale (EDSS) and Functional Systems (FS) in a multiple sclerosis clinical trial. Neurology 1990;40:971-975.

17. Şen S. Neurostatus and EDSS calculation with Cases. Noro Psikiyatr Ars 2018;55(Suppl 1):S80-S83.

18. Uitdehaag BM. Disability outcome measures in phase III clinical trials in multiple sclerosis. CNS Drugs 2018;32:543-558
19. Goodin DS, Reder AT, Bermel RA, et al. Relapses in multiple sclerosis: relationship to disability. Mult Scler Relat Disord 2016;6:10-20.

20. van Munster CE, Uitdehaag BM. Outcome measures in clinical trials for multiple Sclerosis. CNS Drugs 2017;31:217-236.

21. Thompson AJ, Banwell BL, Barkhof F, et al. Diagnosis of multiple sclerosis: 2017 revisions of the McDonald criteria. Lancet Neurol 2018;17:162-173.

22. Kurtzke JF. Rating neurologic impairment in multiple sclerosis: an expanded disability status scale (EDSS). Neurology 1983;33:1444-1452.

23. Çinar BP, Yorgun YG. What we learned from the history of multiple sclerosis measurement: expanded disability status scale. Noro Psikiyatr Ars 2018; 55(Suppl 1): S69-S75.

24. Wachowicz B, Morel A, Miller E, Saluk J. The physiology of blood platelets and changes of their biological activities in multiple sclerosis. Acta Neurobiol Exp 2016;76:269-281

25. Perry VH, Cunningham C, Holmes C. Systemic infections and inflammation affect chronic neurodegeneration. Nat Rev Immunol 2007;7:161-167.

26. Zhang Y, Lin S, Yang X, Wang R, Luo L. Prognostic value of pretreatment systemic immune-inflammation index in patients with gastrointestinal cancers. J Cell Physiol 2019;234:5555-5563.

27. Aziz MH, Sideras K, Aziz NA, et al. The systemic-immune-inflammation index independently predicts survival and recurrence in resectable pancreatic cancer and its prognostic value depends on bilirubin levels: a retrospective multicenter cohort study. Ann Surg 2019;270:139-146.

28. Shi H, Jiang Y, Cao H, et al. Nomogram based on systemic immuneinflammation index to predict overall survival in gastric cancer patients. Dis Markers 2018;2018:1787424.

29. De Larco JE, Wuertz BR, Furcht LT. The potential role of neutrophils in promoting the metastatic phenotype of tumors releasing interleukin-8. Clin Cancer Res 2004;10:4895-4900.

30. Yilmaz A, Mirili C, Bilici M, Tekin SB. A novel predictor in patients with gastrointestinal stromal tumors: Systemic immune-inflammation index (SII). J BUON 2019;24:2127-2135.

31. Wang B, Huang Y, Lin T. Prognostic impact of elevated pre-treatment systemic immune-inflammation index (SII) in hepatocellular carcinoma: a meta-analysis. Medicine (Baltimore) 2020;99:e18571.

32. Chovanec M, Cierna Z, Miskovska V, et al. Systemic immune-inflammation index in germ-cell tumours. Br J Cancer 2018;118:831-838.

33. Casserly CS, Nantes JC, Hawkins RFW, Vallieres L. Neutrophil perversion in demyelinating autoimmune diseases: Mechanisms to medicine. Autoimmun Rev 2017;16:294-307.

34. Naegele M, Tillack K, Reinhardt S, et al. Neutrophils in multiple sclerosis are characterized by a primed phenotype. J Neuroimmun 2012;242:60-71.

35. Keller CW, Lünemann JD. Autophagy and autophagy-related proteins in CNS autoimmunity. Front Immun 2017;8:165.

36. Alirezaei M, Fox HS, Flynn CT, et al. Elevated ATG5 expression in autoimmune demyelination and multiple sclerosis. Autophagy 2009;5:152 158. 